Efficient micropropagation and rooting of Micromeria croatica (Pers.) Schott (Lamiaceae)

Učinkovita mikropropagacija i zakorjenjivanje vrste Micromeria croatica (Pers.) Schott (Lamiaceae)

Kereša, S., Andrijanić, Z., Kremer, D., Habuš Jerčić, I., Barić, M., Batelja Lodeta, K., Bolarić, S., Bošnjak Mihovilović, A.

Poljoprivreda/Agriculture

ISSN: $1848-8080$ (Online)

ISSN: 1330-7142 (Print)

http://dx.doi.org/10.18047/poljo.24.2.4

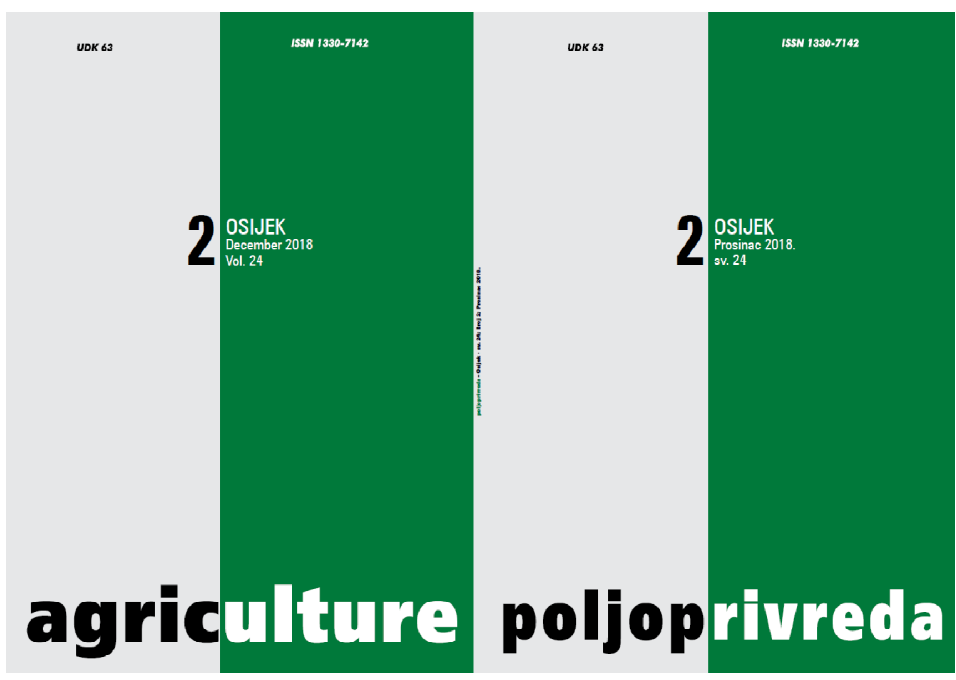

Fakultet agrobiotehničkih znanosti Osijek, Poljoprivredni institut Osijek

Faculty of Agrobiotechnical Sciences Osijek, Agricultural Institute Osijek 


\title{
EFFICIENT MICROPROPAGATION AND ROOTING OF Micromeria croatica (PERS.) SCHOTT (Lamiaceae)
}

Kereša, S.(1), Andrijanić, Z.(1), Kremer, D. (2), Habuš Jerčić, I. ${ }^{(1)}$, Barić, M. ${ }^{(1)}$, Batelja Lodeta, K. ${ }^{(1)}$, Bolarić, S. ${ }^{(1)}$, Bošnjak Mihovilović, A. ${ }^{(1)}$

Original scientific paper

Izvorni znanstveni članak

\begin{abstract}
SUMMARY
Micromeria croatica is an endangered species with a great potential for use as a medical as well as ornamental plant. For commercial use, an efficient propagation protocol is required. The aims of this study were to establish an efficient protocol for micropropagation and rooting of $M$. croatica. A number of factors were tested including the influence of 6-benzylaminopurine (BAP) and 1-naphthaleneacetic acid (NAA) at different concentrations as well as the effect of explant orientation and topophysis on shoot proliferation. Rooting was investigated in agar-based medium supplemented with indole-3-butyric acid (IBA) or indole-3-acetic acid (IAA) at various concentrations. Media with 1 and $2 \mathrm{mg} / \mathrm{L}$ of BAP produced the highest number of shoots/explant. However, the lower concentration of BAP should be recommended due to longer shoots without any sign of hyperhydration. Explant orientation and node position showed equal capability for shoot proliferation. Importantly, $100 \%$ efficiency of rooting was achieved in an agar-based rooting medium. Acclimatisation exceeded $90 \%$. Taken together, an efficient protocol for micropropagation and rooting of $M$. croatica has been established for future production.
\end{abstract}

Key-words: in vitro propagation, Micromeria croatica, plant growth regulators, topophysis

\section{INTRODUCTION}

Micromeria croatica (Pers.) Schott (Lamiaceae) is a perennial shrub species with long stems $(20-30 \mathrm{~cm})$, stalkless leaves, and either pink-purple or white flowers appearing June to August. It is an endemic species to the Dinaric Alps, growing in crevices of calcareous rocks at altitudes of 150-2000 m (Šilić, 1984). Like other species from the Lamiaceae family, $M$. croatica is a rich source of essential oils, whose representative constituents are caryophyllene oxide and E-caryophyllene (Kremer et al., 2012). The presence of these essential oils suggests that $M$. croatica could be useful in the treatment or even prevention of human diseases in which free radicals and other reactive oxygen species have been implicated (Vladimir-Knežević et al., 2011). The use of $M$. croatica has been previously tested with ethanolic extract of $M$. croatica found to ameliorate oxidative stress, inflammation, and fibrogenesis in experimental mice. Furthermore, hepatoprotective and antifibrotic effects of $M$. croatica were comparable to those of silymarin, a well-known standard hepatoprotectant (Vladimir-Knežević et al., 2015). These antioxidant effects have been attributed to high level of phenolic compounds, especially of rosmarinic acid in the $M$. croatica extract. Futhermore, it has also been found out that the leaf extract of $M$. croatica exhibited protective properties against reactive oxygen species-induced DNA damage and inhibited lipid peroxidation (Šamec et al., 2015). Therefore, due to these preliminary but

(1) Prof. Dr. Snježana Kereša (skeresa@agr.hr), Zoe Andrijanić, M. Eng. Agr., Assist. Prof. Ivanka Habuš Jerčić, Prof. Dr. Marijana Barić, Assist. Prof. Kristina Batelja Lodeta, Prof. Dr. Snježana Bolarić, Assist. Prof. Anita Bošnjak Mihovilović - University of Zagreb, Faculty of Agriculture, Svetošimunska cesta 25, 10000 Zagreb, Croatia, (2) Ph. D. Dario Kremer - University of Zagreb, Faculty of Pharmacy and Biochemistry, A. Kovačića 1, 10000 Zagreb, Croatia 
promising results of the medicinal properties of $M$. croatica extract, interest in this species will increase and further research is required. Use of the species as an ornamental plant suitable for small rocky gardens should be considered as well (Karlović et al., 2011).

However, M. croatica has been an endangered species since 2006 and is accordingly a protected species in Croatia, with any collecting of this species from nature leading to possible extermination. Therefore, in the case of commercial use of this species, an efficient propagation protocol is required. Previously it has been noted that vegetative propagation in vivo by cuttings was of low success (D. Kremer, 2014, personal communication). In vitro propagation by axillary branching of different species from the Lamiaceae family was successful (Mehta et al., 2012; Tošić et al., 2015; Bakhtiar et al., 2016; Vinh et al., 2017). Tošić et al. (2015) propagated $M$. croatica using seedlings obtained in vitro as material for culture establishment. However, cloning initiated from adult plant specimen is important when superior chemotaxonomical and/or morphological traits have to be retained for commercial production.

Therefore, the goals of this study were (1) to establish in vitro culture of $M$. croatica from adult plant specimen, (2) to determine the effect of the composition of plant growth regulators (PGRs) as well as the effect of explant orientation on axillary shoot proliferation, (3) to determine the effect of topophysis on axillary shoot proliferation, and (4) to investigate the efficiency of rooting micropropagated shoots.

\section{MATERIAL AND METHODS}

\section{Culture establishment}

As the initial plant material, a single plant provided by the Botanical Garden "Fran Kušan" was used, originally collected from the Velebit nature park (Kuk of Špiljić plane, $44^{\circ} 53^{\prime} \mathrm{N}, 15^{\circ} 16^{\prime} \mathrm{E}$, and $1232 \mathrm{~m}$ above sea level). The plant was grown in a pot in the greenhouse until multiple stems of the shrub reached about $10 \mathrm{~cm}$. For surface sterilisation, those stems were washed under tap water for $15 \mathrm{~min}$, immersed in $70 \%$ ethanol for $1 \mathrm{~min}$, and then immersed again for $15 \mathrm{~min}$ in a solution consisting of $1.5 \%$ sodium hypochlorite $1.5 \%$ active chlorine), $0.1 \%$ Tween $20(\mathrm{v} / \mathrm{v})$, and $150 \mathrm{mg} / \mathrm{L}$ of ascorbic acid. After that the stems were rinsed four times with sterile distilled water supplemented with $150 \mathrm{mg} / \mathrm{L}$ of ascorbic acid. The surface-sterilised stems were, then, used for explant preparation. Apical buds (about $2 \mathrm{~mm}$ long) or one-nodal segments without leaves were cut off and placed on the establishment medium (EM) and cultured in a growth chamber. EM medium consisted of Murashige and Skoog (MS) medium (Murashige and Skoog, 1962), supplemented with $30 \mathrm{~g} / \mathrm{L}$ sucrose, 0.1 $\mathrm{g} / \mathrm{L}$ myo-inositol, $1 \mathrm{mg} / \mathrm{L}$ 6-benzylaminopurine (BAP), 0.1 $\mathrm{mg} / \mathrm{L}$ 1-naphthaleneacetic acid (NAA), $1 \mathrm{~g} / \mathrm{L}$ activated charcoal, $150 \mathrm{mg} / \mathrm{L}$ ascorbic acid, and $8 \mathrm{~g} / \mathrm{L}$ agar (Difco Bacto, USA), with the $\mathrm{pH}$ adjusted to 5.8. A number of subcultures were made on EM (without activated charcoal and ascorbic acid from the second subculture) in order to produce enough material to set up experiments.

\section{Shoot proliferation}

Influence of PGRs constitution and explant orientation on shoot proliferation. After establishment, onenodal segments with leaves were placed vertically or horizontally on the proliferation medium (PM), consisting of MS medium, $30 \mathrm{~g} / \mathrm{L}$ sucrose, $0.1 \mathrm{~g} / \mathrm{L}$ myo-inositol, and $8 \mathrm{~g} / \mathrm{L}$ agar, with the $\mathrm{pH}$ adjusted to 5.8. The PM was supplemented with different concentrations of BAP (0.5-2.0 $\mathrm{mg} / \mathrm{L})$ alone or in combination with NAA $(0.2-1.0 \mathrm{mg} / \mathrm{L})$. In addition, PM medium without any hormone (HFMS) was used as a control. Callus formation and the number of microshoots as well as their length were estimated after each subculture lasted for 45 days.

Influence of node position on the shoot proliferation. In additional experiment, one-nodal segments, from the $1^{\text {st }}$ and $5^{\text {th }}$ node (numbered basipetally) of the uniform shoots (approximately $4 \mathrm{~cm}$ long) were cut off and placed vertically in PM supplemented with $0.5 \mathrm{mg} / \mathrm{L}$ BAP and $0.2 \mathrm{mg} / \mathrm{L}$ NAA. Number of microshoots and their length in this experiment were recorded after 28 days.

\section{Rooting}

Microshoots approximately $1-2 \mathrm{~cm}$ long were taken from PM supplemented with $1 \mathrm{mg} / \mathrm{L}$ BAP. Shoots were placed in agar-based media being either HFMS or HFMS supplemented with different concentrations of indole-3-butyric acid (IBA) $(0.5-1.5 \mathrm{mg} / \mathrm{L})$ or indole3-acetic acid (IAA) (0.5-1.5 mg/L). All together seven different treatments of agar-based rooting medium (RM) were applied. The percentage of rooting, number of roots/shoot, length of the longest root $(\mathrm{mm})$, the mean number of shoots per shrub, and the length of the longest shoot were recorded after 45 days. Rooted plantlets were transferred to a sterile substrate ( $50 \%$ peat, $50 \%$ river sand) filled in ordinary pots and acclimatised in the growth chamber. Throughout all experiments the conditions in the growth chamber were $22^{\circ} \mathrm{C}$ with a $16 \mathrm{~h}$ photoperiod of cool white light $\left(40 \mu \mathrm{E} / \mathrm{m}^{2} / \mathrm{s}\right)$.

\section{Experimental design and statistical analysis}

All the experiments were set up in a completely randomised design. For shoot proliferation, one experimental unit was considered one explant. For the percentage of rooting, the experimental units were Magenta vessels with 9 plantlets. The effect of treatments (PGRs constitution) on shoot proliferation was monitored for three subcultures with 18 explants inoculated per each treatment in each subculture (54 explants per treatment in total). Within each treatment half of the explants were placed vertically and other half horizontally. The topophysis effect was estimated from 90 explants of each node type (1st or 5th). Data from rooting were collected from two successive experiments, each containing 18 
plantlets per treatment. The main effects of the variable tested (PGRs constitution and explants orientation) and their role in shoot proliferation were determined by the General Linear Model, two-way analysis of variance (ANOVA). The effects of explant topophisis on shoot proliferation and rooting were analysed by one-way ANOVA. Bonferroni tests at $\mathrm{P}<0.05$ were performed for mean value comparisons. All analyses were performed using SAS version 9.2 (SAS Institute, 2011).

\section{RESULTS AND DISCUSSION}

\section{Culture establishment}

The apical buds survived culture establishment and were able to form elongated shoots from $94 \%$ of inoculated explants and one-nodal segments from $23 \%$ of explants. In addition, no contamination was recorded. Ascorbic acid and activated charcoal prevented phenolic compounds oxidation and contributed to the survival of explants. As it is important to maintain superior morphological and/or chemotaxonomical traits in the case of commercial production, the process of cloning was initiated from adult plant specimen. Plantlets established from seed germination in vitro could also be source of responding explants as shown by Tošić et al. (2015), however those plants will not be consistent due to the genotypic heterogeneity of the zygotic embryos. In this study, explants survived establishment were subcultured several times on EM medium, until a sufficient number of shoots were obtained to set up the experiment.

\section{Shoot proliferation}

Influence of PGRs constitution and explant orientation on the shoot proliferation. There were 13 different treatments tested, 1 hormone free and 12 varying compositions of PGRs in PM were used in the study of their influence on axillary shoot proliferation. It was found out that the number of microshoots and their length significantly $(\mathrm{P}<0.001)$ depended upon the different compositions of PGRs in the medium. However, neither explant orientation nor the interaction of these two factors showed any significant influence on the axillary shoot proliferation. All the treatments produced axillary shoots, but the highest number (18.5 shoots) of long enough shoots/explant were obtained on the $1 \mathrm{mg} / \mathrm{L}$ BAP medium, making this study most successful to date (Table 1, Figure 1a). This number of shoots is six times higher than it has been previously found for other species of the Lamiaceae family such as Mentha piperita (Mehta et al., 2012.), Thymus persicus (Bakhtiar et al., 2016), and Lavandula angustifolia (Vinh et al., 2017). In addition, the previous attempts at micropropagating M. croatica, and closely related species, Micromeria juliana, obtained 10.34 and 9.39 shoots/explant on MS medium containing $1 \mathrm{mM}$ kinetin and $3 \mathrm{mM}$ benzyladenine plus 0.57 mM IAA, respectively (Tošić, 2015; Tošić et al., 2015). However, it should be noted that counting of new microshoots in this study was performed after 45 days, while previously it has been performed after four weeks. Therefore, it seems that the extra time of subcultivation had an increased effect of axillary shoot proliferation in $M$. croatica.

Table 1. Efficiency of the shoot proliferation of Micromeria croatica depending on the constitution of PGRs Tablica 1. Efikasnost proliferacije izdanaka vrste Micromeria croatica u ovisnosti o sastavu biljnih regulatora rasta

\begin{tabular}{|c|c|c|c|c|}
\hline \multicolumn{2}{|c|}{$\begin{array}{c}\text { PGRs constitution (mg/L) } \\
\text { Sastav biljnih regulatora rasta (mg/L) }\end{array}$} & \multirow{2}{*}{$\begin{array}{l}\text { No. of shoots/explant } \\
\text { Broj izdanaka/eksplantatu }\end{array}$} & \multirow{2}{*}{$\begin{array}{l}\text { Shoot length }(\mathrm{mm}) \\
\text { Dužina izdanaka }(\mathrm{mm})\end{array}$} & \multirow{2}{*}{$\begin{array}{l}\text { Callus diameter }(\mathrm{cm}) \\
\text { Promjer kalusa }(\mathrm{cm})\end{array}$} \\
\hline BAP & NAA & & & \\
\hline 0 & 0 & $2.9 \mathrm{~d}$ & $5.0 \mathrm{c}$ & 0.0 \\
\hline 0.5 & 0 & 13.7abc & $9.2 \mathrm{ab}$ & 0.0 \\
\hline 0.5 & 0.2 & 9.4abcd & $10.9 a$ & $0.5-1.0$ \\
\hline 0.5 & 0.5 & $8.2 \mathrm{bcd}$ & $6.8 \mathrm{bc}$ & $0.5-1.0$ \\
\hline 0.5 & 1.0 & $6.7 \mathrm{~cd}$ & $4.0 \mathrm{c}$ & $0.5-1.0$ \\
\hline 1.0 & 0 & $18.5 a$ & $11.3 a$ & $<0.5$ \\
\hline 1.0 & 0.2 & 11.7abcd & 7.9abc & $<0.5$ \\
\hline 1.0 & 0.5 & $7.7 \mathrm{~cd}$ & 7.1abc & $0.5-1.0$ \\
\hline 1.0 & 1.0 & $6.6 \mathrm{~cd}$ & $4.7 \mathrm{c}$ & $0.5-1.0$ \\
\hline 2.0 & 0 & $18.2 \mathrm{ab}$ & $6.9 a b c$ & 0.0 \\
\hline 2.0 & 0.2 & $15.8 \mathrm{abc}$ & $8.0 a b c$ & $<0.5$ \\
\hline 2.0 & 0.5 & 13.2abc & $6.4 \mathrm{bc}$ & $0.5-1.0$ \\
\hline 2.0 & 1.0 & 11.2abcd & $3.7 \mathrm{c}$ & $0.5-1.0$ \\
\hline
\end{tabular}

Values within the column followed by the same letter are not significantly different according to Bonferroni tests at a $P<0.05$ 
Almost identical results were obtained for $2 \mathrm{mg} / \mathrm{L}$ BAP. However, the shoots were shorter when grown on this treatment (Table 1). Moreover, the concentration of cytokinins under these growth conditions caused hyperhydration in a certain number of shoots clusters. Though it is known that a higher concentration of PGRs can lead to an increased risk of somaclonal variation, it is most suitable to use a lower concentration of BAP (Bairu et al., 2011; Viehmannova et al., 2016). In addition, callus formation tended to be higher in media where NAA was used in combination with BAP. Increase in concentration of NAA from $0.2-1 \mathrm{mg} / \mathrm{L}$ also decreased the number of shoots/explants (Table 1).

On the other hand, explant orientation (vertical or horizontal) did not influence the number of new shoots produced. The average number of shoots/explants across all the treatments was 11 regardless of whether they were set horizontally or vertically. This has been previously seen in a study of axillary shoot induction between node segments of Cosmos artrosanguineus placed vertically or horizontally (Kozak et al., 2013). In this study the explants were quite short (one-nodal) and therefore as a consequence the buds all had a similar exposure to the PGRs, regardless of their orientation, which most likely diminished the possible influence that explant orientation may have on proliferation.

Influence of node position to the shoot proliferation. The different node position ( $1^{\text {st }}$ and $\left.5^{\text {th }}\right)$ used as an explant was found out to have no statistical significance on the success of micropropagation of $M$. croatica. The average number of shoots/explant after 28 days in culture was 5.1 on the $1^{\text {st }}$ node and 5.2 on the $5^{\text {th }}$ node. Length of the shoots was also similar and amounted 9 $\mathrm{mm}$. The positional effects on subsequent growth or development of explants or topophysis can be quite large, and therefore an understanding of topophysis for optimised selection of initial explants can significantly improve the efficiency of a micropropagation system (George and Sherrington, 1993; Lee-Espinosa et al., 2008).
Previously, it has been found out that in vitro cultured axillary rose buds from the medial section of the parent shoot developed more rapidly than either apical or basal buds (Bressan et al., 1982). Furthermore, it has been previously found out that growth from axillary buds of roses increased acropetally (Zieslin et al., 1976). However, the results in this study correlate to earlier work that found out equal capability for shoot proliferation (on medium supplemented with 6-benzyladenine) of younger, $4^{\text {th }}$ or $5^{\text {th }}$, as well as older cotyledonary nodes in the organogenic culture of eucalypt (Corymbia torelliana $\times$ C. citriodora) (Hung and Trueman, 2011). Though they found out strong, negative morphogenic gradients in shoot elongation, proliferation and rooting from the cotyledonary to the $4^{\text {th }}$ or $5^{\text {th }}$ node of the seedlings their nodes were transferred to the node culture without 6-benzyladenine.

\section{Rooting}

It has been previously established that a number of species from the Lamiaceae family are very conducive for in vitro rooting, with very high rooting efficiency found for Ocimum basilicum, Mentha piperita, and Thymus persicus (Asghari et al., 2012; Mehta et al., 2012; Bakhtiar et al., 2016). In correlation with these, there was $100 \%$ efficiency of rooting microshoots of $M$. croatica in both HFMS and RM supplemented with $0.5-1.5 \mathrm{mg} / \mathrm{L} \mathrm{IBA}$ and $0.5 \mathrm{mg} / \mathrm{L} \mathrm{IAA}$ (Table 2, Figure $1 \mathrm{~b}$ ). However, lower root induction was seen in explants grown in agar-based medium supplemented with $1 \mathrm{mg} / \mathrm{L}$ IAA. Additionally, roots were found out to be the longest when microshoots were rooted in RM supplemented with $1 \mathrm{mg} / \mathrm{L} \mathrm{IBA}$. Importantly, microshoots continued to develop axillary branching during the rooting process as seen in Figure 1c. Furthermore, micro-shrubs were calculated to have on the average 3.8 shoots when grown in HFMS medium (Figure 2). This is extremely desirable, as $M$. croatica is a naturally bushy plant and potential use of this species either as ornamental or for medical purposes would require as higher branching as possible.

Table 2. Efficiency of rooting in agar-based rooting medium using varying compositions of PGRs

Tablica 2. Efikasnost zakorjenjivanja u mediju s agarom, uz različit sastav biljnih regulatora rasta

\begin{tabular}{|c|c|c|c|c|}
\hline \multicolumn{2}{|c|}{$\begin{array}{c}\text { PGRs constitution (mg/L) } \\
\text { Sastav biljnih regulatora rasta (mg/L) }\end{array}$} & $\begin{array}{c}\text { Rooting response (\%) } \\
\text { Uspješnost zakorjenjivanja (\%) }\end{array}$ & $\begin{array}{c}\text { No. of roots/shoot } \\
\text { Broj korjenčića/izdanku }\end{array}$ & $\begin{array}{c}\text { Length of the longest root (mm) } \\
\text { Dužina najdužega korijena (mm) }\end{array}$ \\
\cline { 1 - 2 } IBA & IAA & $100.0 \mathrm{a}$ & $2.6 \mathrm{a}$ & $18.6 \mathrm{bc}$ \\
\hline 0 & 0 & $100.0 \mathrm{a}$ & $2.3 \mathrm{ab}$ & $17.6 \mathrm{bcd}$ \\
\hline 0.5 & 0 & $100.0 \mathrm{a}$ & $2.3 \mathrm{ab}$ & $24.1 \mathrm{a}$ \\
\hline 1.0 & 0 & $100.0 \mathrm{a}$ & $1.3 \mathrm{c}$ & $22.3 \mathrm{ab}$ \\
\hline 1.5 & 0.5 & $100.0 \mathrm{a}$ & $1.9 \mathrm{bc}$ & $19.1 \mathrm{ab}$ \\
\hline 0 & 1.0 & $78.0 \mathrm{~b}$ & $2.6 \mathrm{a}$ & $13.5 \mathrm{~cd}$ \\
\hline 0 & 1.5 & $93.0 \mathrm{a}$ & $1.6 \mathrm{c}$ & $12.9 \mathrm{~d}$ \\
\hline
\end{tabular}

Values within the column followed by the same letter are not significantly different according to Bonferroni tests at a $\mathrm{P}<0.05$ 
Acclimatisation efficiency exceeded $90 \%$ when the substrate was sterilised before planting (Figure 1d) and no differences in acclimatisation efficiency was recorded between the different rooting treatments. Plants sporadically started to bloom during acclimatisation and this was also the case during prolonged in vitro cultivation. Furthermore, acclimatisation in non-sterilised substrate failed. However, a fungicide treatment of the substrate could help in this case.
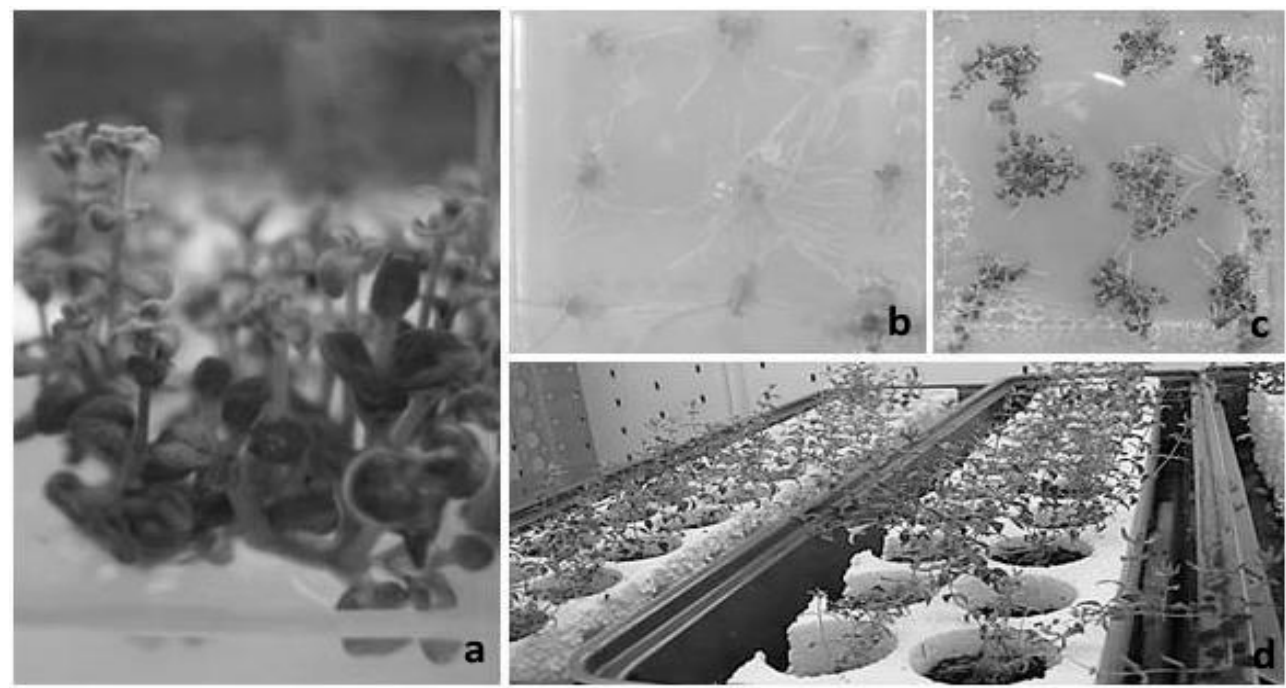

Figure 1. a) Shoot proliferation on PM medium supplemented with $1 \mathrm{mg} / \mathrm{L} \mathrm{BAP,}$ b) Rooting of $M$. croatica in HFMS, c) Axillary branching during rooting, d) Plants acclimatised in sterile substrate

Slika 1. a) Proliferacija izdanaka na PM mediju s dodatkom $1 \mathrm{mg} / \mathrm{L}$ BAP-a, b) Zakorjenjivanje M. croatica u HFMS mediju $s$ agarom, uz dodatak $0.5 \mathrm{mg} / \mathrm{L} I A A, c)$ Aksilarno grananje tijekom zakorjenjivanja, d) Biljke aklimatizirane u sterilnome supstratu

\section{Number of shoots/shrub}

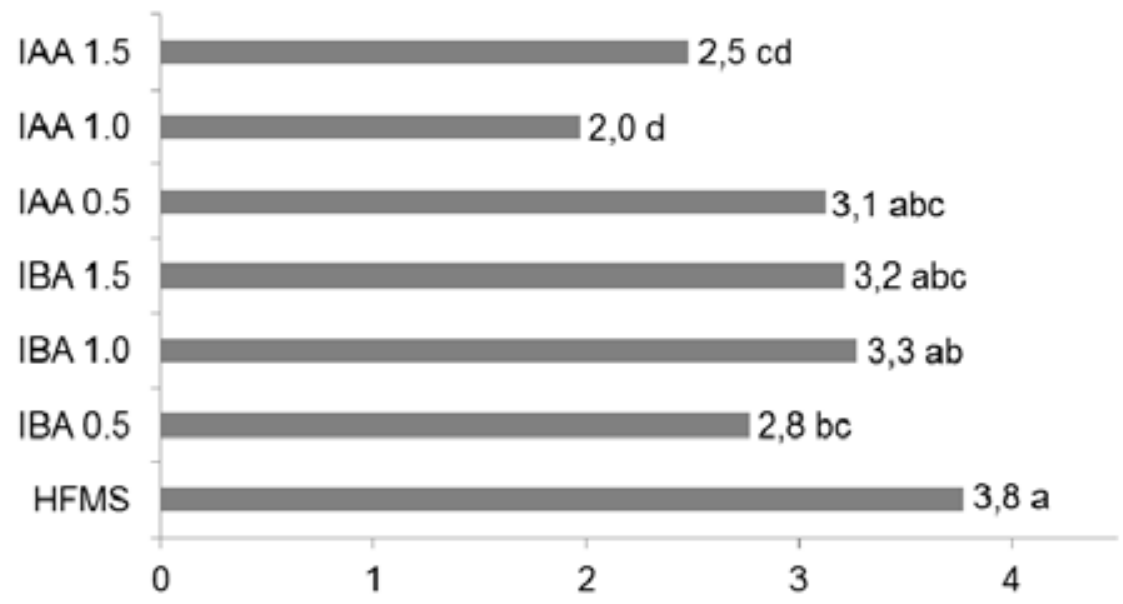

Figure 2. Effect on the number of shoots/shrubs of varying concentrations of auxins (IBA, IAA) during rooting Slika 2. Utjecaj različitih koncentracija auksina (IBA, IAA) na broj izdanaka po grmiću tijekom zakorjenjivanja

\section{CONCLUSION}

In conclusion, an efficient protocol for the micropropagation by axillary branching from adult plant specimen and rooting in agar-based medium was established for $M$. croatica. Due to a number of valuable bioactive compounds as well as ornamental perspective, interest is continually growing for $\mathrm{M}$. croatica. In this study it was found out that media supplemented with $1 \mathrm{mg} / \mathrm{L}$ and $2 \mathrm{mg} / \mathrm{L}$ of BAP had similar micropropagation efficiency. However, the lower BAP concentration should be recommended as the shoots were longer and the chance for somaclonal variation is considered lower. 
Additionally, an explant orientation of vertical or horizontal and varying node positions showed equal capability for shoot proliferation. Importantly, 100\% efficiency of rooting was obtained in agar-based medium without PGRs as well as in rooting medium supplemented with IBA $0.5-1.5 \mathrm{mg} / \mathrm{L}$ and IAA $0.5 \mathrm{mg} / \mathrm{L}$. The longest roots were obtained in RM with $1 \mathrm{mg} / \mathrm{L}$ IBA, but this did not have an effect on the acclimatisation efficiency of the explants with a $90 \%$ efficiency achieved in a sterile substrate. In the future, rooting using the agar-based hormone-free medium should be used, with shoots continuing to develop by axillary branching during the rooting process. It is an important feature to consider in the commercial production of $M$. croatica.

\section{REFERENCES}

1. Asghari, F., Hossieni, B., Hassani, A., \& Shirzad, H. (2012). Effect of explants source and different hormonal combinations on direct regeneration of basil plants (Ocimum basilicum L.). Australian Journal of Agricultural Engineering, 3(1), 12-17. https://pdfs.semanticscholar. org/b305/6f6f58b58826df562efb0fe15f0904f7e2b3.pdf

2. Bairu, M. W., Aremu, A. 0., \& Van Staden, J. (2011). Somaclonal variation in plants: causes and detection methods. Plant Growth Regulation, 63(2), 147-173. https://doi.org/10.1007/s10725-010-9554-x

3. Bakhtiar, Z., Mirjalili, M. H., \& Sonboli, A. (2016). In vitro callus induction and micropropagation of Thymus persicus (Lamiaceae), an endangered medicinal plant. Crop Breeding and Applied Biotechnology, 16(1), 48-54. https://doi.org/10.1590/1984-70332016v16n1a8

4. Bressan, P. H., Kim, Y. J., Hyndman, S. E., Hasegawa, P. M., \& Bressan, R. A. (1982). Factors affecting in vitro propagation of rose. J. Amer. Soc. Hort. Sci, 107(6), 979-990. https://www.researchgate.net/ profile/Scott_Hyndman2/publication/264993092 Factors_affecting_in_vitro_propagation_of_rose/

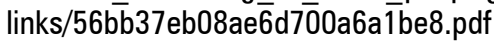

5. Hung, C. D., \& Trueman, S. J. (2011). Topophysis effects differ between node and organogenic cultures of the eucalypt Corymbia torelliana x C. citriodora. Plant Cell, Tissue and Organ Culture (PCTOC), 104(1), 69-77.

6. Karlović, K., Hodja, M., Kremer, D., \& Kosalec, I. (2011, January). Morphological variability of leaf and flower traits in Micromeria croatica (Pers.) Schott. In VII International Symposium on New Floricultural Crops. Scientific Program and Abstracts /Facciuto, G., Greppi, J., Perez de la Torre, M. (Eds.), Buenos Aires-Argentina: Ediciones INTA-GESyC, p. 25

7. Kozak, D., Pogroszewska, E., \& Szmagara, M. (2013). The influence of type and orientation of explants on in vitro growth and development of Cosmos atrosanguineus (Hook.) Voss. Acta Sci Pol Hortorum Cultus, 12(1), 41-53. https://www.hortorumcultus.actapol.net/pub/12_1_41. pdf

8. Kremer, D., Stabentheiner, E., Dunkić, V., Müller, I. D., Vujić, L., Kosalec, I., ... \& Bezić, N. (2012). Micromorphological and chemotaxonomical traits of Micromeria croatica (Pers.) Schott. Chemistry \& Biodiversity, 9(4), 755-768. https://doi.org/10.1002/cbdv.201100121
9. Lee-Espinosa, H. E., Murguıa-Gonzalez, J., GraciaRosas, B., Cordova-Contreras, A.L., Laguna-Cerda, A., Mijangos-Cortes, ... \& Santana-Buzzy, N. (2008). In Vitro Clonal propagation of Vanilla (Vanilla planifolia 'Andrews'). HortScience, 43(2): 454-458. https://hortsci. ashspublications.org/content/43/2/454.full.pdf

10. Mehta, J., Naruku, R., Sain, M., Dwivedi, A., Sharma, D., \& Mirza, J. (2012). An efficient protocol for clonal micropropagation of Mentha piperita L. (Pipperment). Asian Journal of Plant Science and Research, 2(4), 518-523. https://www.vitalbiotech.org/images/VBT004.pdf

11. Murashige, T., \& Skoog, F. (1962). A revised medium for rapid growth and bioassays with tobacco tissue cultures. Physiologia plantarum, 15(3), 473-497. https:// doi.org/10.1111/j.1399-3054.1962.tb08052.x

12. Šamec, D., Gruz, J., Durgo, K., Kremer, D., Kosalec, I., Žulj, ... \& Piljac-Žegarac, J. (2015). Molecular and cellular approach in the study of antioxidant/pro-oxidant properties of Micromeria croatica (Pers.) Schott. Natural product research, 29(18), 1770-1774. https://doi.org/10. 1080/14786419.2014.999334

13. SAS Institute (2011). The SAS system for Windows. Release 9.2. SAS Institute, Cary, NC.

14. Šilić, Č. (1984). Endemične biljke (p. 114). Sarajevo: Svjetlost.

15. Tošić, S. M. (2015). Fiziološki i biohemijski aspekti propagacije endemičnih vrsta Micromeria pulegium (Rochel) Benth. i Micromeria croatica (Pers.) Schott in vitro (Doctoral dissertation, Univerzitet u Beogradu-Biološki fakultet).

16. Tošić, S., Nikolić, S., Jovanović, M., Zlatković, B., \& Stojičić, D. (2015). Micropropagation of Micromeria juliana (L.) Benth. ex Rchb. (Lamiaceae). Biologica Nyssana, 6(1), 17-23. https://journal.pmf.ni.ac.rs/bionys/index.php/bionys/article/view/127/87

17. Viehmannova, I., Cepkova, H. P., Vitamvas, J., Streblova, P., \& Kisilova, J. (2016). Micropropagation of a giant ornamental bromeliad Puya berteroniana through adventitious shoots and assessment of their genetic stability through ISSR primers and flow cytometry. Plant Cell, Tissue and Organ Culture (PCTOC), 125(2), 293-302. https://doi.org/10.1007/s11240-016-0949-X

18. Vinh, D. T., Hoa, M. T. P., Khai, P. C., \& Minh, T.V. (2017). Micropropagation of lavender (Lavandula angustifolia L.). Journal of Innovations in Pharmaceutical and Biological Sciences (JIPBS), 4(2): 7-11. https://www.jipbs.com/ VolumeArticles/FullTextPDF/292_JIPBSV4I202.pdf

19. Vladimir-Knežević, S., Blažeković, B., Štefan, B.M., Alegro, A., Kőszegi, T., \& Petrik, J. (2011). Antioxidant activities and polyphenolic contents of three selected Micromeria species from Croatia. Molecules, 16(2), 1454-1470. https://doi.org/10.3390/molecules16021454

20. Vladimir-Knežević, S., Cvijanović, O., Blažeković, B., Kindl, M., Štefan, B.M., \& Domitrović, R. (2015). Hepatoprotective effects of Micromeria croatica ethanolic extract against $\mathrm{CCl} 4$-induced liver injury in mice. BMC Complementary and Alternative Medicine, 15(1), 233. https://doi.org/10.1186/s12906-015-0763-8

21. Zieslin, N., Haaze, H., \& Halevy, A. H. (1976). Components of axillary bud inhibition in rose plants. II. The effect of bud position on degree of inhibition. Botanical Gazette, 137(4), 297-300. 


\section{UČINKOVITA MIKROPROPAGACIJA I ZAKORJENJIVANJE VRSTE Micromeria croatica (PERS.) SCHOTT (Lamiaceae)}

\section{SAŽETAK}

Hrvatska je bresina (Micromeria croatica) ugrožena biljna vrsta, s velikim potencijalom uzgoja u medicinske svrhe i kao ukrasna biljka. Za komercijalnu primjenu, nužan je učinkovit protokol za propagaciju. Cilj ovoga rada bio je uspostavljanje učinkovitoga protokola za mikropropagaciju i zakorjenjivanje vrste M. croatica upotrebom odrasle biljke kao izvora početnoga materijala. Testiran je velik broj faktora, uključujući utjecaj 6-benzilaminopurina (BAP) i 1-naftalen octene kiseline (NAA) u različitim koncentracijama, kao $i$ utjecaj orijentacije eksplantata $i$ topofizis efekta na proliferaciju izdanaka. Zakorjenjivanje je ispitivano u mediju s agarom, uz dodatak indol-3-maslačne kiseline (IBA) ili indol-3-octene kiseline (IAA) u različitim koncentracijama. Mediji s 1 ili 2 mg/L BAP-a producirali su najveći broj izdanaka/eksplantatu, međutim preporuča se niža koncentracija BAP-a, na kojoj su dobiveni duži izdanci, bez znakova hiperhidracije. Orijentacija eksplantata i nodiji s različitih pozicija na izdanku pokazali su jednaku sposobnost proliferacije izdanaka. Na mediju s agarom postignuta je $100 \%$ uspješnost zakorjenjivanja. Uspješnost aklimatizacije bila je iznad 90\%. Zaključno, razvijen je učinkovit protokol za mikropropagaciju i zakorjenjivanje vrste M. croatica za moguću buduću proizvodnju.

Ključne riječi: in vitro propagacija, Micromeria croatica, biljni regulatori rasta, topofizis efekt

(Received on 30 May 2018; accepted on 26 November 2018 - Primljeno 30. svibnja 2018.; prihvaćeno 26. studenoga 2018.) 